\title{
AUTHOR(S): PEACH, A
}

TITLE:

Thinking through craft.

YEAR: $\quad 2009$

Publisher citation: PEACH, A. 2009. Thinking through craft. Journal of design history [online], 22(1), pages 82-84. Available from: https://doi.org/10.1093/jdh/epn044

OpenAIR citation: PEACH, A. 2009. Thinking through craft. Journal of design history, 22(1), pages 82-84. Available from: https://doi.org/10.1093/jdh/epn044

Publisher copyright statement:

This is the AUTHOR ACCEPTED version of an article originally published by

OuP in Journal of design history

(ISSN 0952-4649; eISSN 1741-7279).

This is a pre-copyedited, author-produced version of an article accepted for publication in Journal of Design History following peer review. The version of record is available online at: https://doi.org/10.1093/jdh/epn044.

\section{OpenAIR takedown statement:}

Section 6 of the "Repository policy for OpenAIR @ RGU" (available from http://www.rgu.ac.uk/staff-and-currentstudents/library/library-policies/repository-policies) provides guidance on the criteria under which RGU will consider withdrawing material from OpenAIR. If you believe that this item is subject to any of these criteria, or for any other reason should not be held on OpenAIR, then please contact openair-help@rgu.ac.uk with the details of the item and the nature of your complaint.

This publication is distributed under a CC_ BY-NC 4.0 license.

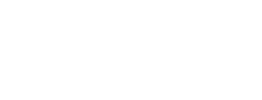


Thinking Through Craft

Glenn Adamson. Berg, 2007. 209 pp., 43 b\&w illus., 16 col. pls, £15.99 pbk. ISBN: 9781 845206475

Peter Dormer's excellent edited volume The Culture of Crafts (1995), considered the status and future of craft at the close of the twentieth century, and was key in mapping the critical terrain for the apparent marginality of craft. Once again this marginalisation has become the focus of critical attention. It would seem that craft and its related discourse persists as evidenced by the recent proliferation of critical texts on the subject including: Exploring Contemporary Craft - History, Theory \& Critical Writing, edited by Jean Johnson (Coach House Books and Harbourfront Centre, 2002), Objects and Meaning New Perspectives on Art and Craft, edited by M. Anna Fariello and Paula Owen (Scarecrow Press, 2004), The Beauty of Craft - A Resurgence Anthology edited by Sandy Brown and Maya Kumar Mitchell (Green Books, 2004), Craft in Dialogue - Six Views on a Practice in Change edited by Love Jönsson (IASPIS, 2005), Howard Risatti’s A Theory of Craft - Function and Aesthetic Expression (The University of North Carolina Press, 2007), Richard Sennett's The Craftsman (Allen Lane, 2008) and NeoCraft: Modernity and the Crafts, edited by Sandra Alfoldy (Nova Scotia College of Art and Design, 2008). As the titles here seem to suggest, craft in the twenty first century is presenting something of a problem to thinkers, who grapple to find meaning and purpose in something that has in equal measures the ability to embarrass, confuse and inspire. Despite the American Craft Museum in New York's decision in 2003 to expunge craft from its name, rebranding itself the Museum of Arts and Design, and the UK Crafts Council decision to effectively dispense with its public face by closing its two shops and London gallery in 2006, it is encouraging to see that craft, and all its attendant baggage, endures as a subject of scholarly debate.

Glenn Adamson is well qualified to take up the challenge of craft in his book Thinking Through Craft, which, rather than provide a celebratory or historical context to craft, seeks to approach it as a theoretical concept. Adamson, who is Deputy Head of Research and Head of Graduate Studies at the V\&A, trained as an art historian in the United States 
and has worked as a curator and lecturer. He has published widely on craft, contributed to the 2007 V\&A exhibition Out of the Ordinary $-21^{\text {st }}$ Century Craft, and is an editor of Berg’s Journal of Modern Craft (2008), which he helped launch. In Adamson’s opinion, what has been missing is a text that 'treats craft as an idea' (p. 1). Whereas, the texts cited above also aim to address the need for more critical writing on craft, they are broader in scope and ambition, providing essays which explore craft from a variety of viewpoints and genres, ranging from history, production, theory and culture. Most are geographically located and the product of conference papers on the same subject. Adamson's book, single-authored, and self-consciously theoretical, is perhaps most directly comparable with Risatti’s A Theory of Craft, also published in 2007. Whereas both Risatti and Adamson argue for the need to propose a theory of craft, Risatti attempts to challenge stereotypes about craft and argue for the recognition of craft as art. Adamson, on the other hand, dismisses the idea that the crafts can or should in any way be considered art, and in this sense provides an original take on the 'problem' that is craft: 'my central argument ... is that craft's inferiority might be the most productive thing about it.' (p. 5). This lack of apology is what makes Adamson's book an interesting, if contentious read. As previous writers have struggled to argue for the recognition of craft in the canon of art theory, Adamson dispenses with this notion by proposing a positive take on craft's perceived inferiority, a status he argues that makes it so interesting and demanding of further analysis. He does not specifically propose that craft adopt a critique of its own, which is something of a disappointment (his references are almost all from art history and theory), but he does robustly position craft as a subject worthy of further theoretical attention.

The book is divided into five chapters, each considering an idea or an approach to how one might begin to theorise craft, focusing on the themes of: the supplemental, the material, skill, the pastoral and the amateur. As such, Adamson outlines the beginnings of what could be a useful taxonomy of craft theory, although he points out that his intention is to be suggestive rather than comprehensive. The first two chapters are concerned with addressing craft as a problem case within modern art history, pitching fine art and craft against each other, through the analysis of key terms and their subsequent application to 
specific case studies. In chapter one, Adamson explores Derrida's theory of the supplement with relation to craft, and juxtaposes it with the uncompromising concept of autonomy, a key Greenbergian idea underpinning modern artwork. Can these terms ever be reconciled or will one always be subservient to the other? Adamson examines the possibilities, by considering case studies ranging from Brancusi to contemporary jewellery, to artists who have used craft to challenge the canon of autonomy (such as the Pattern and Decoration movement of the late 1970s), and those who choose to exploit craft's supplementarity as an ideological trope (Droog design).

Chapter two provides a parallel to chapter one's analysis of the binary opposition of autonomy and supplementarity, by contrasting the concepts of the material and the optical, as related to craft and fine art respectively. Craft's specific engagement with the material, Adamson argues, is what differentiates it from modern art, which strives to transcend the physical. Here Adamson presents case studies which illustrate contradictions in the antithetical concepts of the material and the optical, focusing on Anthony Caro’s 1962 sculpture Early One Morning and the work of the 1960s Process Artists. This chapter concludes with a comparison of the work of glass artists Dale Chihuly and Emma Woffenden. Both makers deal with material processes of extraordinary skill, but come from very different theoretical positions. Chihuly's work, often derided by contemporary art critics, illustrates the problem of craft that is devoid of critical content. Woffenden's work, Breath (1992), on the other hand, is considered as an example of what conceptual thinking through craft might look like.

The concept of skill is, as Adamson argues, at the core of his thinking through craft, and is the subject of chapter three. Here Adamson challenges the notion of skill being superfluous to the making of art, by revisiting Jackson Pollock's aphorism, 'Technique is just a means of arriving at a statement' (p. 69), and considers how skill has come to be something of an embarrassment in contemporary art. This chapter revisits the work of key theorists writing about craft, such as David Pye, Michael Baxandale, Joseph Albers, John Dewey, Charles Jencks and Kenneth Frampton, illustrating that we are far from 
resolved in terms of how we understand, teach and value skill in twenty-first century visual culture.

The last two chapters focus on areas of craft practice which present the most difficultly for critical thinkers - the pastoral and the amateur. Here Adamson examines the craft revival of the 1970s and the coinciding rise of counterculture, and uses case studies from the Cotswolds, Appalachia and Korea to argue that craft can exemplify both positive and negative aspects of the pastoral. He considers issues of cultural inferiority associated with home craft, by juxtaposing hobby craft with the avant garde, an area where craft has most recently come to the attention of artists such as Mike Kelley and Tracey Emin, whose work capitalises on the idiom of craft's inferiority to fine art.

It is in writing about the work of Emin that Adamson's thesis of celebrating the 'problem' of craft is finally brought home: 'for all that craft is an embarrassment for the construct of modern art, it seems that the modern art world cannot do without it.' (p. 163). This statement sums up Adamson's thinking through craft, which tends to view craft largely through the lens of fine art practice. A point also made by Charles Darwent in his review of the same text in Crafts (No. 210, January/February, 2008), who argues that Adamson's use of art historical theory to compare craft with art ensures that craft will always be the loser. It is important to note that many of Adamson's case studies do come from fine art and studio craft practice, an imbalance that will be particularly noted by design historians and students of material culture. Adamson acknowledges this imbalance in his conclusion, where he reiterates that his intention is to see craft 'not as a subject for celebration or self-congratulation, nor as a disqualification for serious artistic enterprise, but rather as a problem to be thought through again and again.' (p.168). This book does just that, and despite the fine art bias, is recommended to both art and design theorists, and anyone else anxious to engage in theorising about craft.

\author{
Andrea Peach \\ Lecturer in Contextual and Critical Studies \\ Gray's School of Art
}


Robert Gordon University

Aberdeen 